\title{
Remaining an Outsider. An Eighteenth-Century Diary of a Hungarian Nobleman
}

\author{
Gábor Csikós
}

Hungarian Academy of Sciences - Institute of History

\section{ABSTRACT}

György Nagy was an eighteenth-century merchant and nobleman in the Jászság region, and his diary for the period 1759 to 1769 gives insights into his selfidentity. Even though it is not explicitly stated, the document is infused with a sense of being an outsider.

This study attempts to find the bases of this sentiment using the methods of cultural psychology, and seeks to explore his particular responses to conflicts that arose in his life. Four factors can be identified which made the diary's author an outcast: (i) Nagy came from outside the Jászság region; (ii) his university-level education and profession distinguished his lifestyle from that of the landed peasant majority; (iii) his identity as a member of lower nobility; (iv) the conjunction and combination of these circumstances all at once. It was Nagy's ancestry which was the principal determinant his self-image and exercised the greatest influence over his decisions (loans, etc.). Other factors (his decision to move to the region, his intellectual tendencies) speak of his individuality. This dichotomy is present in the very act of keeping a diary as well: even though he was working for the good of a broader group (his family), the urge to preserve a piece of his self is apparent from his writing. As for Nagy's descendants, the importance of these qualities declined; they integrated into local society as the sources of otherness disappeared. The only exception was his youngest son, a Law graduate (the grandfather of Iván Nagy, a genealogist), who continued to keep the diary, as did his offspring. Thus, atypical tendencies were preserved by the atypical. ${ }^{1}$

Keywords: diary, lower nobility, eighteenth-century Hungary, mentalities 


\section{MAGYAR NYELVÜ ABSZTRAKT}

Nagy György egy 18. században élt jászsági kereskedő és nemes volt, akinek 1759 és 1769 között készült naplója bepillantást enged identitásába. A kívülállóság érzete átszövi az írás egészét, még akkor is hs ez nyílt kimondásra nem került.

Jelen tanulmány ennek az érzésnek az alapját keresi pszichológiai megközelítésben és igyekszik feltárni a naplóíró sajátos válaszait azokra a konfliktusokra, amelyek az életében történtek. Négy tényező azonosítható, amely a napló szerzőjét kívülállóvá tette. A Jászságon kívülről származott, egyetemet végzett, kereskedői pályája pedig lakóhelyének paraszti többségétől választotta el. Kisnemesi identitása szintén meghatározó. Ezek a komponensek együttesen tették kívülállóvá a helyi társadalomban.

Nagy György ősei meghatározóak voltak önképének kialakításában és nagyban befolyásolták döntéseit (kölcsönök). Más tényezők (döntése a költözésről, intellektuális irányai) azonban az egyéniségéről vallanak. Ez a kettősség a naplóra is jellemző: noha a napló megírását főleg az indokolta, hogy egy nagyobb csoportot segítsen (családját), a vágy, hogy lényének egy darabját megőrizze az utókornak szintén jelen van.

Mivel a leszármazottak számára a kívülállás tényezői már nem voltak jelen, integrálódtak a helyi társadalomba. Az egyetlen kivétel a legkisebb fiú (Nagy Iván genealógus nagyapja), aki jogot végzett és folytatta a naplót. Így tettek az utódai is. Tehát az atipikus jellemzőket végül egy másik atipikus családtag vitte tovább.

Kulcsszavak: napló, kisnemesség, 18. századi Magyarország, mentalitás

'Biographies are but the clothes and buttons of the man. The biography of the man himself cannot be written' (Mark Twain ${ }^{2}$ ). The memory of György Nagy's 'silver filigree buttons for his pelisse's and other moments in his life were preserved by his diary written between 1759 and 1769 .

Who was György Nagy? From his autobiography, we know he was born on $14^{\text {th }}$ April 1706 in Szécsény. After finishing his secondary education in 1726 he moved to Pozsony (nowadays Bratislava in Slovakia) in order to take up juridical studies and to improve his German. He married in 1730, and his wife, Rozália Helle (1715-1790) bore him four children, all of whom reached adulthood. They lived in Jászárokszállás, where he took some positions in the local administration. As a trader, György traveled frequently. He passed away on $28^{\text {th }}$ April 1770.

His diary is relatively an early example of its kind by Hungarian standards. Such basic requisites of the genre as paper production, the measurement and perception of linear time, or the growing interest towards the self were accomplished only gradually and came to maturity in the $19^{\text {th }}$ century. ${ }^{4}$ Diaries are records following a progressing dateline that inform us of events, experiences and feelings that the author has 
encountered. ${ }^{5}$ The writing of György Nagy partially conforms to this definition, at least between 1759 and 1769. However, it also mixes the elements of memoir and chronicle writing. Moreover, inventories and other family documents were also added to the diary, including the memoir of his late grandfather, who died in 1697. So, in some parts this diary is more than a hundred years older than the Hungarian golden age of diary-writing.

This relatively old age has another effect, besides the mixed style. György Nagy's personality appears only in an indirect way: he rarely elaborates his feelings or ruminations, so we need to judge them by cryptic signs. For example, the act of combining his and his grandfather's scripts shows the importance of the family traditions to György Nagy. Although he chose a different path in life to that of his ancestors by leaving their hometown and not following their military traditions, those ancestors certainly remained an important influence on his identity. ${ }^{6}$

These decisions and changes unquestionably had a great effect on his personality, and it is that personality which is analyzed here on the basis of/through/with the help of his diary for the years 1759 to 1769 . Living more than forty years in Jászárokszállás proved to be insufficient for his total integration into Jász society, and he remained somehow an outsider till his final hour had come. Despite the town's ethnic or linguistic homogeneity, his diary constantly indicates the lack of a sense of belonging to the local community. Although explicit mention of his being an outsider is made only once, when he explains his decision to refuse the offer of an administrative post in $1746^{7}$, there are several allusions which reveal his separation from the majority. For example, he rarely mentions local events: the charters of market towns (1746; 1756), the building of the church (1745) and the foundation of high school (1768) represent the sum total of his references to his place of residence. By way of contrast, Parma is mentioned three times, Vienna six, Belgium nine, and France twenty-five times. Protests against the Act of Redemption (1745) or the murder of a young man by the soldiers of the Royal Infantry Regiment ${ }^{8}$ are passed over in silence, while local farmers are referred to only by their surnames. As writing a diary is a process of selection of what is and what is not important, it can be assumed, that Nagy did not set much store in recording the town's public life.

In the interpretiation of this diary, the approach will be psychological. It is necessary to focus on the interactions of an individual mind and a given culture using only sporadic documentation. The sporadic nature of the documentation might indeed cause trouble ${ }^{9}$, but gaps exist in clinical investigations which aim to reveal the psychical state of the ascendants. Despite this lack, a reliable impression can indeed be obtained ${ }^{10}$ without hindering the use of this approach in historical research. So, this 
study focuses on 1) identifying the components of Nagy's identity, and 2) exploring how these features strengthened his being an outsider, and motivated him to keep a diary.

\section{MOTIVATIONS FOR WRITING THE DIARY AND CONSTRUCTING AN IDENTITY}

György Nagy emphasized the practical reasons for his keeping of a diary: 'I started to write this protocollum ${ }^{11}$ with the purpose of registering the main and necessary things of my few stock, family and children.'

Given the situation in late feudal Hungary, in which proof of nobility brought numerous advantages, this function cannot be simply ignored, as the collected documents did indeed prove the family's nobility. ${ }^{12}$ Among these advantages were the facts that, as subjects of the monarch's authority, nobles could only be arrested following due legal process, and were exempt from all taxes.

This technical goal was the most important in the eyes of his descendants, too, as they continued collecting legal documents under the title Memorialis (worth remembering). This was probably also a pivotal motivation for György Nagy, who started to write the diary the year after he had written: 'travelling to my advocate in Pest was expensive.' His work as the city treasurer in the previous years might have also reinforced in his mind the importance of written words. An additional impetus was that in 1759 he was convinced by the local notary to present all his personal documents to the city council. ${ }^{13}$

György Nagy's work is far from being a mere inventory, though. Although the keeping of diaries and the writing of autobiographies are commonly regarded as a sign of self-consciousness, the abundance of information on the history of the family suggests the coexistence of some collectivist traits, too. The narrative is the most fundamental form of organizing and communicating information ${ }^{14}$ including the construction of identity. In order to detect the collectivist and individualist goals text analysis is used. As the text is not so explicit, the incidence of adjectives might help the reader in classifying positive and negative attitudes and possibly emotions. The following figure demonstrates the frequency of adjectives in the diary:

So, in total, forty instances of negative expressions appear, while the adjective 'good' alone can be found fifty-five times, while 'kind' occurs twenty times and 'beautiful' eighteen. Hence, the expression of negative feelings remains very limited. In addition, some adjectives are not completely or always negative. 'Poor' is also used to signal an acceptance of the inevitability of life's travails, as in the cases when he writes about the 


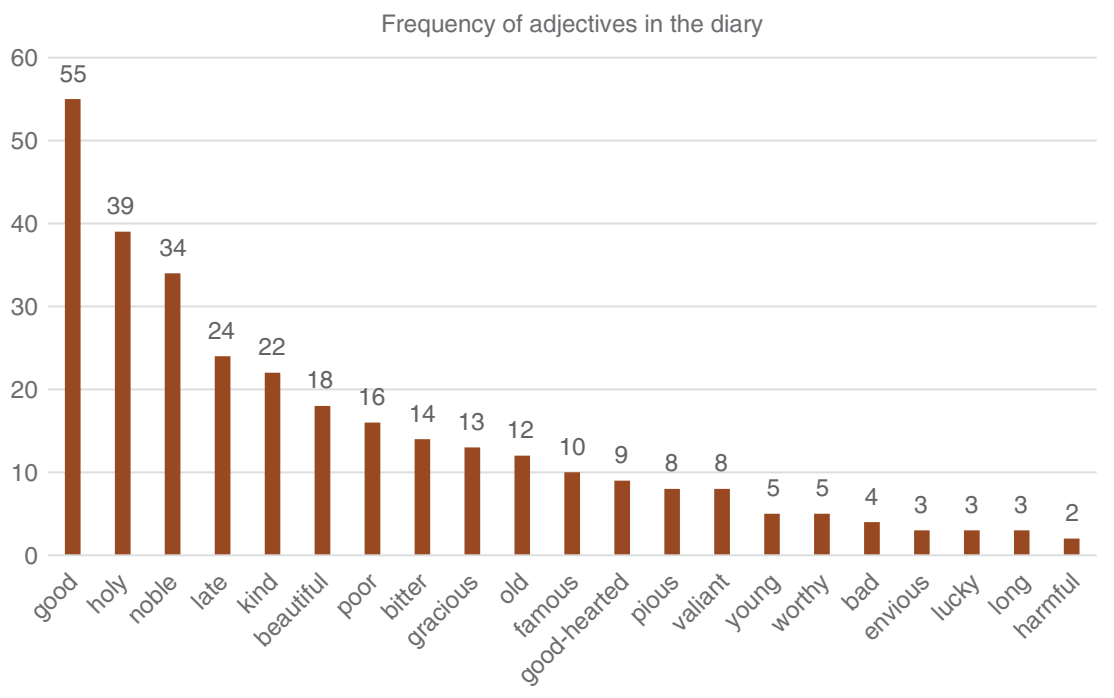

Figure 1: Frequency of adjectives in the diary (Atlas.ti).

sufferings of his wife. And bitter is also used to present a humble attitude towards life. (As the diary starts: 'Before I would use my slight talent to record my life story which was bitter and full of sufferings I see it necessary to report about the origin of my family.')

So, 'envious' and 'bad' can be regarded as core components in the expression of negative attitudes. The adjective 'envious' appears once with reference to the distant past (when his grandfather was recalling a family conflict with a captain in the 1570 s) ${ }^{15}$ and once again in the description of an international conflict. ${ }^{16}$ Subsequently, this adjective is mentioned only twice in personal relations: when Nagy reports the death of another György Nagy, the notary of Jászberény, who was his 'envious enemy, who wanted to connect himself to my family, this was the origin of his anger. May he rest in peace. Amen. ${ }^{17}$ With those closing phrases, he shows a will to an act of reconciliation even in the case of one whom he regarded in a negative light.

Another major conflict in Nagy's life was with his sister. He gives a relatively detailed description of it, enclosing some legal documents concerning the matter, too. 'Greater troubles and anguish struck me this year due my sister Katarina Szabó née Nagy, who was the relicta (widow) of my former brother-in law and who incommoded me unceasingly with her inheritance rights. Exhorted by evil, envious people she launched a legal procedure against me. ${ }^{18}$ As this short passage illustrates, Nagy was able 
to recognize extenuating circumstances for his sister's act even in such a serious conflict.

In conclusion, it can be assumed that he wanted to preserve both his positive self-image (one of generosity and benevolence) and the good reputation of the family, with an eye to the wide readership of the diary in the future.

Nagy was over fifty when he started keeping the diary, and in 1758 his beloved wife nearly died due to an illness: declining health and approach of death slowly became a part of the family's life. Although it had been ten years previously, Nagy was moved to quote his late father's reaction to discovering the signs of aging: 'Multa senex plangit, quando instat et angit.' (The old man bewails many things when death stands by and tightens its grip. $)^{19}$ So, psychological factors played an important role in diary writing.

Looking back on his life it is possible that Nagy sought coherence and meaning. Writing may also offer a chance to right the injustices in life..$^{20}$ This was a strong factor in the case of György Nagy, who gave a detailed description of the time when his family disintegrated. His efforts in this direction are clear in his analysis of the events and his quest for a deeper meaning to his father's disastrous decisions during the war.

Finally, joy is also a motivation in diary writing. Even if writing is a lonely activity, it fulfills a communicative need too by imitating a kind of conversation..$^{21}$ Possibly György Nagy needed and enjoyed this kind of loneliness, as he also had a book collection that he listed in his inventory. By the early eighteenth century, what had hitherto often been a communal activity, with one or more people reading aloud, was giving ground to silent reading, turning reading into an entertainment to do alone..$^{22}$

\section{BRIEF HISTORICAL BACKGROUND}

The last decades of the seventeenth century were turbulent in Central Europe. The Ottoman Empire lost almost all its Hungarian territories (conquered after 1526) to the Habsburg Empire. The Great Turkish War (1683-1699) restored the Hungarian Kingdom under the rule of Holy Roman Emperor Leopold I, but these historical merits did not make him a popular ruler. He viewed himself not as a liberator but a conqueror. Hungary became a 'newly acquired territory' instead of 'territory liberated from the Ottomans', so the lands formerly taken away from the Hungarian nobility by the Ottomans were returned only to those who could prove their rights with documents and could pay $10 \%$ of its worth to the Habsburgs. If they failed to do so, the property went to the creditors of the Empire. ${ }^{23}$

Leopold I enforced decisions disadvantageous to the Jászság region too. The Jász people-probably of Iranian origin—fled to Hungary with the 
Cumans in the thirteenth century, and received privileges from Hungary's rulers. The Jász were to a certain extent self-governing, and their status was above that of serfs but below nobles.' Under Ottoman rule their political and economic freedom was suspended, and after a few years of independence, Leopold I sold them to the Teutonic Order, regarding the territories as his private property. This decision made the Jász protest, and after a while they took sides with Ferenc Rákóczi, leader in the War of Independence, which started as a peasant revolt in 1703, but quickly burgeoned, attracting all those who were not satisfied with the policy of Leopold I.

János Nagy, the father of the diary writer was also a rebel, and led his troops as a colonel. The nearly decade-long insurrection was brought to an end by Treaty of Szatmár. The Hungarian nobility, however, managed to defend Hungarian interest, at least in part. Jászság got its lord back, but in 1731 the Teutonic Order sold the Jászság to the Invalidenhaus in Pest. The Invalidenhaus was founded for soldiers who were injured in the Great Turkish War, and by the early eighteenth century it had become one of the biggest health care complexes in Hungary. The income from the Jászság served as an economic support for the operation.

Although a more liberal economic policy was conducted at that time than previously, the local elite continued its freedom movements. The Act of Redemption in 1745 liberated the people of Jászság from many of the feudal dues and services, and this freedom attracted many. Among others, one of these advenas was György Nagy.

\section{'ADVENA STATE'}

Leaving home was a decisive experience for György Nagy.

Nagy's diary interprets the family history as the mythos of autumn, the tragedy. ${ }^{24}$ The hubris of the Nagy family was that the father - who became a captain for his merits in the War of the Spanish Succession - deserted the emperor's army and joined the rebels in the Rákóczi War of Independence. In Nagy's words: 'My father got involved in this labyrinth. If only God had hindered him from diving into this uproar causing terrible losses to him and his descendants. ${ }^{25}$

The mother' death in November 1708 was a devastating loss that accelerated the dissolution of the family. The children were taken into care by relatives: two-year-old György remained in his home town with his uncle, but his eleven-year-old sister was taken to Heves County. His father could not manage his properties due his absence, so he decided to sell many at low prices. (In his son's words it was 'preying of buyers.') However, his other valuables did not remain intact either. During the occupation of the city, imperial soldiers requisitioned his livestock; his house was looted 
and vandalized, and a servant who tried to defend the goods was beaten. 'They looted everything leaving only an empty barn, empty chambers, a hutch and the bare walls.' ${ }^{26}$

After three years (so, in 1711) the family was able to reunite for a short time, but no longer in Szécsény. The father, fearing revenge for his rebellious stance, decided to leave the county and move to Rahó (nowadays Рахiв, in the Ukraine) where his second wife - the former widow of Ferenc Rákóczi's chancellor - possessed lands. ${ }^{27}$ György Nagy described her as a 'tolerable' stepmother, even if she was selfish and more interested in fashion than raising children ${ }^{28}$. So, after the death of János Nagy in 1713, the children returned to the families who they had been living with before 1711. György was only seven years old at that time. His maternal relatives did their best to preserve the family properties that survived the War of Independence. But in 1719 another tragedy struck when the house was damaged in a fire, burdening the family budget with the high expenses of repairs.

In 1728 György Nagy decided to sell his entire property and move to Jászság.

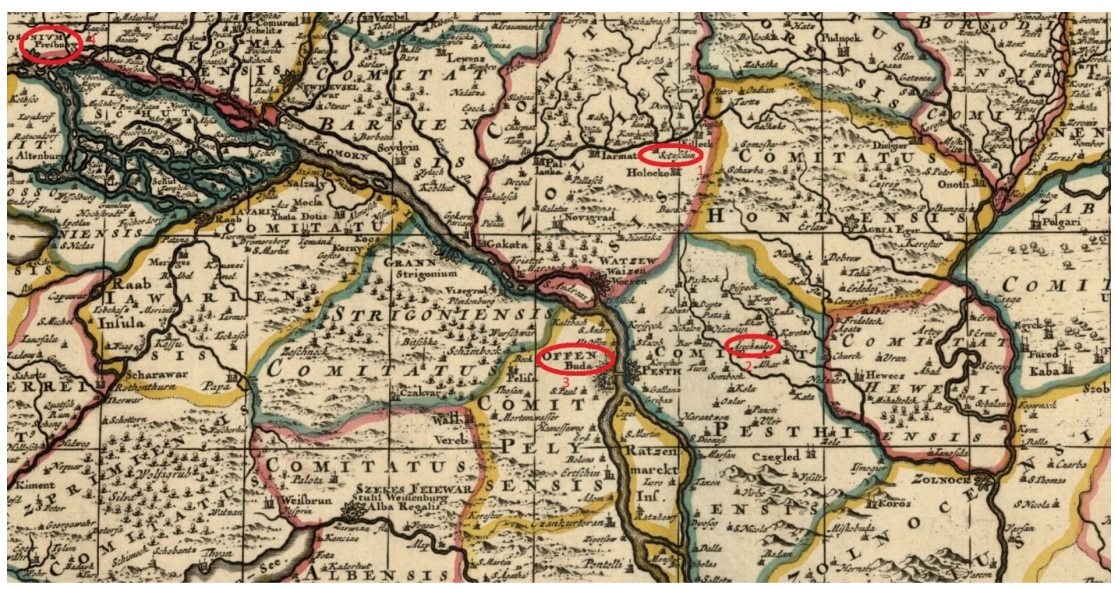

Map 1: 'Regnum Hungariae in Omnes suos Comitatus'29 (early eighteenth century). The numbers refer to towns that were of importance in the life of György Nagy: 1. Szécsény; 2. Jászárokszállás; 3. Buda; 4. Pozsony (today Bratislava).

This surely cannot have been an easy decision. Home and its physical features provide emotional security; the feeling of familiarity and the intimacy can form the foundation of the sense of autonomy. The grief felt 
when the home is destroyed physically or psychically is similar to the loss of people important to one. Therefore, migration can be perceived as a multiple loss. ${ }^{30}$ For György Nagy, home may well have had even greater importance, given the constant presence of the family in Nógrád county through generations.

The grandfather's narrative also displays strong emotional bonds to this region. Geography triumphs over time and actors, because the first bonds to reality in the grandfather's story are represented by places. $\mathrm{He}$ set up no universal time-frame, and people are even mentioned using mythological names (e.g. Geurus, Ursur, Torzol, Tárkány, Dedus, Briccius). Actors and time seem unreal, but the geography is pure reality: the places could easily identified. It is obvious that all the stories were set in Northern Hungary, and especially in Nógrád county. One of the family's forefathers, Geurus founded Diósgyőr, after his merits became apparent in the occupation of Sajókér. (His name was probably Latinized by the grandfather from the city name Györ.)

The history of the family was preserved on both the spiritual and material planes. The red marble grave marker of a family member who died in 1517 was kept by the descendants, and built it into the wall of the family house, as witnessed by the grandfather in 1663 when visiting relatives, and for the sake of the 'posteri' he drew the monument and added it to his memoir.

The importance of Nógrád county did not fade with the centuries; the family stayed there and the grandfather made detailed records of those family members who left this region because of wars (to Eger, Ónod, Fülek) or studies (Nagyszombat). Further-off places (e.g. Hollókő or Veszprém) were mentioned because family members moved there, but these are only marginalia. There is an unspoken rule expressed in the comments: if you leave Nógrád, you will perish. ${ }^{31}$

György Nagy also had to confront this rule when he left Szécsény. In fact, he resided just a few years in Szécsény due his turbulent family history and his studies, but the traditions expressed in the grandfather's manuscript created a strong bond between him and his family. On the advice of a family friend, the parish priest of Vámosgyörk, Nagy moved to Jászárokszállás. He met his future wife in the priest's house, too; but it was probably not only these family ties that informed his decisions. At this time, some men from Nógrád county were already living in Jászárokszállás. He asked two of them - János Csizmadia and Pál Baghy, good friends of his late father - to be the witnesses at his wedding in 1729. Later, György Nagy lists more names, so it may be assumed that a small community with its origins in Nógrád lived in Jászárokszállás at that time. 


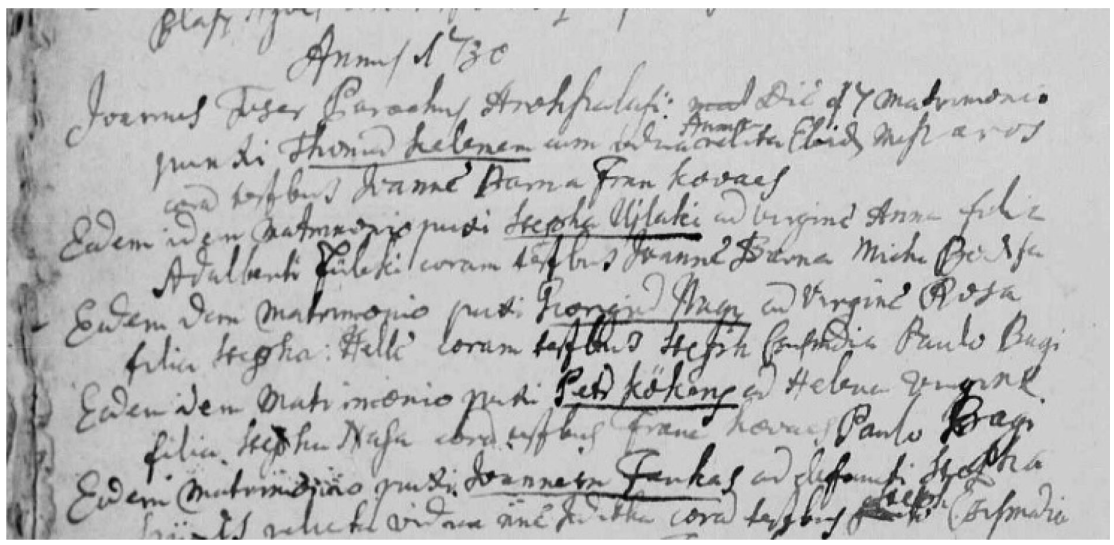

Picture 1: Marriage certificate of György Nagy. ${ }^{32}$

What is more, there may well have been additional reasons for the choice of Jászárokszállás as a future residence. First, the town's location was favorable: the trade roads to major Hungarian cities (Pest or Debrecen) were easily accessible. ${ }^{33}$ Secondly, the inhabitants still enjoyed a more liberal economic policy than the surrounding villages (and the majority of Hungarians). Nagy was indeed a nobleman, so his privileges were valid throughout the whole country, though it was not a matter of indifference to him how the other villagers - including his neighbors - lived. And the future was promising, as the hope for later redemption emerged after the Diet declared in 1715 that the Jászság was not sold, but pawned..$^{34}$ Finally, the Act of Redemption in 1745 offered a wide range of economic and political opportunities for many, so this free peasant society attracted many.

In Jászárokszállás, $8 \%$ of the families were of noble origin, coming mostly from Northern Hungary. ${ }^{35}$ In 1698, however, an investigation revealed that 200 villagers were actually former serfs who had fled from their landlords. ${ }^{36}$ So, not surprisingly, the local census showed that only half of the population was native. And, the designation of someone as 'native' in the census was intended to mean only that his ancestors had been living in that place in 1620. Immigration continued in the early eighteenth century. (Between 1735 and 1745 the number of farms rose by $40 \%$ : from 246 to 343 . $)^{37}$

So, it is questionable whether Nagy's non-native origin could have caused any great disadvantage in such a heteronomous city. In 1745 Baron István Orczy tried to convince him to join the local administration, but Nagy refused the offer, stating that he wanted to avoid further 
conflicts and wished to leave such posts for natives. Although the council alluded to his honor and good reputation ${ }^{38}$, he continuously highlighted his foreignness, even one year after the redemption and seventeen years after his moving to Jászság.

It is practically certain that there could have been some people who reminded him of his origin, but there was also a community that approved of him, otherwise it is hard to explain why they constantly tried to convince him to take important administrative positions. In 1752, he accepted appointment as the city treasurer, but refused to become a judge in 1758. His decision was explained by his experiences in 1752: satisfying the obligations in the city council was cumbersome, and therefore he had little time to carry on the business.

Refusing participation in the political life of Jászárokszállás was a commitment to the preservation of his outsider status. His reasoning also stressed that: his business was primarily trade ${ }^{39}$ and not the animal husbandry or crop production that was common among the free peasants of Jászság. So, his retirement from local decision-making led him to another island of outsider status; being a trader, a profession requiring a commitment to both to keeping accounts and diaries. ${ }^{40}$

\section{THE TRADER}

The prestige of trade was low in Jászság. Cultivators did not show much interest towards this profession, so most of the merchants were of foreign origin. Although they were commonly called Greeks, in fact many came from Albania or Armenia, sharing visibly different ethnic and religious backgrounds to that of the majority. ${ }^{41}$ Their cultural norms and values were also distinct. While the traditional cultivator was set up as an example of one who worked hard with his family on their land, these merchants were not 'tied to their country. ${ }^{42}$ Being a trader demanded a rather more mobile lifestyle than the cultivators', and the importance of profit often carried greater weight for them than tradition. This attitude was clearly seen in the case of György Nagy as well. First, he planned to trade in wine, but the advice of his friends convinced him that trading in animals would be more profitable.

By the 'opening of spring' in 1730 he had bought 22 steers and 28 calves in Jászberény, these became the cornerstone of his later wealth. 1730 fell in a period of abundance. Even the plague of locusts in 1731 had favorable effects on his economic situation, because he could buy livestock at low prices, yielding a tolerable income in following years. The fairs of Pest and Szécsény in 1732 were also successful, resulting in sufficient funds for the purchase of land and the building of a barn. This promising upswing 
was interrupted by some disasters in the 1740s: pestilence in 1740 and drought in 1746. He also suffered several losses in 1767, when his loans have not been repaid. 'The earnings of many years of hard work are lost.' - he wrote in a melancholy mood/he wrote melancholically.

Despite these sorrowful events, he still managed to prosper in business: he became a well-known trader at many fairs - including those of Pest, Kecskemét and Debrecen - and amassed a fortune which counted as significant on a local level. His inventory illustrates his wealth: beside agricultural tools, it lists a pocket watch, bookshelves, tin vessels, teaspoons and paintings on canvas, too - i.e. things that were not common in a market town milieu. ${ }^{43}$ So his material culture also differed from that of the common people, and this difference was rooted in his education. He was an educated man, and this feature strengthened his identity as an outsider.

\section{THE EDUCATED MAN}

Nagy completed his university studies in 1726, and moved to Pozsony in order to improve his knowledge of German and set himself up in legal practice. Hence, he was an educated man by the standards of the eighteenth century and surely by the standards of his place of residence, too.

Although Matthias Bél (1684-1749) depicted the Jászság favorably, stating that 'all of the Jász people are literate...many of them know Latin as well. ${ }^{44}$, these appreciative statements surely contain some degree of exaggeration. Even the head of the Jász administration, captain Mátyás Nagy (1678-1775) had only completed secondary education and did not attend university. ${ }^{45}$ Later a thin stratum of intellectuals formed. The captain's son, István (1731-1780) studied in Vienna and became a Jesuit priest, but generational differences probably hindered the formation of a friendship between him and György Nagy. Jász intellectuals are seldom mentioned by György, with the exception of Mihály Zatkó (1695-1755), the priest of Jászárokszállás. They were surely on good terms, as Zatkó became godfather to two of Nagy's children.

(It is worth mentioning that we know little concerning Nagy's thoughts on God and religion. He commonly wrote about the acts of religious observance performed by his wife and daughter, including making aims or the acquisition of indulgences. ${ }^{46} \mathrm{He}$ did commonly register the important events in the local the Catholic church, like the building of new churches or the death of notable members on local, national and even international levels. He recorded the fire in Constantinople that 'destroyed more than sixty Christian houses.' His writing reveals that his attitudes towards God were possibly characterized by Divine Providence, 
as the following passage illustrates: 'This was such a woeful year that I will keep it grievously forever in my memory: it was the trial from God for I will praise His name and beg Him not to visit such events even upon my descendants. ${ }^{, 47}$ So, these examples may illustrate that religion played an important role in his life.)

In 1746, in recognition of the high level of György Nagy's education, Baron István Orczy suggested nomination to office in the District to him, given the generally lower level of education to be found among the native population. ${ }^{48}$ Nagy, however, refused this opportunity, fearing the conflict his newcomer status might cause. Given the previous analysis of the thencontemporary population's origin in Jász, it was not a well-grounded reason, but rather an excuse or pretext. More probable is that his retirement from the public sphere was motivated by his determination to remain an outsider, as also maybe his introverted personality.

Knowledge was important to Nagy. This is demonstrated not only by his library (numbering twenty-seven volumes), but also by the very act of starting to write a diary. ${ }^{49}$ The contents of his writing reveal an intellectual man possessed of great curiosity. He travelled frequently and wrote about events worth seeing including a military exercise in Rákos and the plans and the construction of Buda Castle (1749) or the visit of Queen Maria Theresa to Vác (1764). He was deeply interested in world politics and recorded events in Venice, the Papal States or the Ottoman Empire. He mentions France 25 times, Prussia 20, Spain 7, and even distant Sweden merited 3 mentions. He also reported unusual natural phenomena including the comet of 1744 , an exceptional storm (1748), or the earthquake of 1763.

Another factor that might show the importance of knowledge is that he depicted his grandfather ${ }^{50}$ as an 'educated, clever, pious man' ${ }^{51}$, emphasizing the intellectual characteristics of a soldier.

In the light of the high esteem in which knowledge was held, it can be assumed what a great conflict for György Nagy it was to accept his sons' decision not to follow him in becoming an intellectual. The eldest son, András, started his university studies in Eger, but after a year he quit because had no intention of studying and was more interested in farming. When György traveled to Eger to take his son home, a solar eclipse occurred. This may well have been a symbolic event in his eyes. 'Birds hid in their nests and the cattle lowed and horses neighed" ${ }^{52}-$ he wrote of the darkness that surely expressed his inner feelings too.

The other son, János, did not fulfill paternal desires that he get a higher education, either. He started college in Eger, but left after two years, in 1760 , because he instead obeyed his mother's will, and stayed at home. ${ }^{53}$

The family's intellectual tradition seemed to remain without a successor until the youngest son, József Nagy (1755-1809), finally obtained 
a degree in Law and became the notary of Jászapáti. Although these events occurred after the death of György Nagy, the tradition of education did not die out. József's son, Ferenc (1788-1843), moved back to Nógrád county, where he became an archivist. It was he who found the diary; it had since been augmented with some notes on family accounts by József Nagy, but had then disappeared for a couple of decades. It was rumored that the daughters of András Nagy had hidden it, but finally in 1820 Ferenc Nagy found the document among the odds and ends of his brother, Gábor, and swapped it for a 'time-worn double barreled gun. ${ }^{54}$ His son, Iván Nagy (1824-1898) was a renowned historian who gained his fame for his fundamental and comprehensive works in genealogy. As they continued the diary, their contributions at the same time helped the document survive.

\section{THE NOBLE}

The fourth source of György Nagy's status as an outsider was his noble origin. He constantly emphasized the importance of his nobility by giving a detailed description of his family. ${ }^{55}$ The family's function is not only the accumulation of economic, cultural or symbolic privileges, but also the forum for the sharing of common emories. ${ }^{56}$ Furthermore, there are two types of family: a physical one with which we live, and a symbolic family that helps us to orientate in life. Members of the symbolic family have the function of role models, and family narration can transfer the most important values ${ }^{57}$ While personal remembrance commonly summarizes only the history of three or four generation ${ }^{58}$, György Nagy reported on approximately eleven. (The time span extends over eight centuries.)

It cannot be a coincidence that the time horizon of the family history is identical with the history of Hungary. The first Nagy probably appeared at the time of Hungarian conquest of the Carpathian Basin. Though the diary does not mention this event, it may be inferred that this ancestor was a pagan warlord who occupied Sajókér, a town located in Northern Hungary. Members of the Nagy family witnessed or participated in all the focal events of medieval Hungary. They mourned dead heroes after the battles of Varna (1444) and Mohács (1526), and the great kings (Sigismund of Luxembourg, Vladislaus I, and Matthias I) recognized their merits and supported them. In 1431 they received a charter that made them noble, but in the grandfather's interpretation this was only a affirmation of their ancient nobility. The anti-Ottoman wars brought the third charter - in 1593 - for his valor during the siege of Fülek (near Szécsény, the hometown of György Nagy). The narrative shows that the 
Nagy family were never slow to come to the defence of their country in times of difficulty.

The importance of his own family is recurrently emphasized in the pages of Nagy's diary. The most spectacular case happened in 1758 February, when an unknown man greeted him at the fair of Gyöngyös. The stranger soon declared that they were distant cousins from the grandmother's side, so regarding their family bonds he asked for some money. György Nagy lent him some, and the man promised that he would pay it back soon. This, however, did not happen. In 1771 the children's notes show that 'the money is lost.'

In György Nagy's view, glory is only for the members of Nagy family's Felsőgyőr branch. He does not mention other important nobles, including the administrative leader (captain) of Jászság, Mátyás Nagy (16781775), or András Pethes (1736-1805), who was a member of the Royal Hungarian Bodyguard founded by Maria Theresa, Queen of Hungary.

He was not interested in locals, but constantly made references to people with high ranks. For example, there are more than 200 comments on the royal family or the Queen herself, while his family members merited just over 70 mentions. On the basis of the family history we might expect mixed sentiments towards the monarch. If this was so, it was not manifested in the diary. The Queen was described in completely positive terms (her epithets are 'majestic' or sometimes 'gracious'), and slightly critical attitudes can only be found with regard to certain nobles. When Count Antal Grasalkovits (1694-1771) held a ball, Nagy mentioned that the Count had been a poor student, and many envied his luck both in his career and in being in the Queen's good graces. ${ }^{59}$

Rebels - except for Rákóczi, who was referred to only by his official title of prince, with no adjective - were depicted in a completely negative light. In 1754, when Nagy was in Buda, he 'followed his curiosity' and watched the execution of a rebel leader ${ }^{60} \mathrm{He}$ interpreted the rebellion led by Pera Segedinac in 1735 as follows: 'in this year another memorable event happened, as the soldiers had left the country because of the French War, so the Serbs raised a rebellion around Szeged against Her Majesty and the Hungarian nation ... They preyed, destroyed and looted the goods of the lords and the people and this tumult lasted until the time they got their deserved penalties. ${ }^{61}$ He used very similar terms about the rebel in Croatia too: 'In 1755 the Wallachians started a tumult by killing their officers and priests, they burnt the mansion of the Zagrabian count and looted the livestock of bishops and lords. Finally, the nobility had had their fill of this rampant savagery and rose against them. ${ }^{62}$ Even if György Nagy was never in military service, these quotes shed light on the positive image of the nobility as savior of the nation in times of need just like in times of yore. 
How did this proud self-image compare to the reactions of local people? Unfortunately, we know little about these reactions. But the reputation of the nobility was possibly not so high in a free peasant society that regarded the Act of Redemption as the greatest merit of the Monarchy. Complains from the late eighteenth century registered that these free peasants did not respect nobles and state officers and they did not pull their cart to the side of the road and in many cases they did not even greet them. ${ }^{63}$

\section{THE SOURCES OF BEING AN OUTSIDER}

Four factors can be identified that make the diary-writer an outsider in the society in which they live. Probably none of these characteristics taken in isolation would have made him outsider, but their combination effectively weakened his connections to and ability to connect to the majority.

The most obvious factor is that he was a newcomer. Although this theory was also expressed by Nagy himself, it can hardly be accepted as the sole reason, as after all, the volume of migration in the early eighteenth century was extremely high. Additionally, his life story and personality also contradict this theory. He was not a victim of circumstances, a man drifting with the tide. Being a merchant influenced his decision to move to Jászság, which had good access to the most important Hungarian markets. However, this was a rare profession in local society, plus his university education also characterized him as an outsider in the free peasant community. His noble mentality is another layer of his identity: several times he expresses the belief/conviction that the history of the nobility is identical with the history of Hungary. When he wrote about important historical events he demonstrated that it was the national level that he was interested in, and not the local.

This, however, was not the case with his sons. They were native to the society of Jászság - each of them was born in Jászárokszállás - and they also wanted to remain so. Two sons became cultivators who did not value the noble origin much; the participation of the Nagy family in the Act of Redemption carried greater importance for them. The 1828 census contained only three nobles with the surname Nagy, which number soon sank to two in 1850. It must be noted, however, that Gáspár Nagy (17831851), who was the grandson of György Nagy was missing from this list. ${ }^{64}$

So, only a few decades were enough to erase the sources of this being an outsider. The only exception was the youngest son of György Nagy, József (1755-1809). He and his descendants preserved the diary and continued it later. This demonstrates that for the survival of a manuscript written by an atypical man in his milieu, the help of another atypical one was needed. 


\section{SOURCE}

Nagy, György: Nemes Nagy György jászsági naplója, 1759-1769 (1820). (The diary of György Nagy from Jászság. 1759-1769 (1820)) ed. Csikós, Gábor. Szolnok: MNL Jász-NagykunSzolnok Megyei Levéltára, 2017.

\section{WORKS CITED}

Bagi, Gábor. A Jászkun Kerület társadalma a redempciótól a polgári forradalomig, 1745-1848. (The Society of the Jászkun District from the Redemption to the Revolution, 1745-1848) Szolnok: Jász-Nagykun-Szolnok Megyei Múzeum Igazgatósága, 1995.

Bánkiné Molnár, Erzsébet. 'A jászkun autonómia.' (The jászkun Autonomy) In: Bánkiné Molnár Erzsébet (ed.), Autononóm közösségek a magyar történelemben. (Autonomous Communities in Hungarian History). Kiskunfélegyháza: Kiskun Múzeum Baráti Köre, 2003, 119-128.

Berne, Eric. What Do You Say After You Hello? The Psychology of Human Destiny. New York: Grove Press, 1972.

Boreczky, Ágnes. A szimbolikus család. (The Symbolic Family) Budapest: Gondolat Kiadó, 2004.

Botka, János. 'A Jászkunság tényleges nemeseinek összeírása 1850-ből.' (The Census of Genuine Nobility in Jászkunság from 1850) In: Zounuk, 6. Szolnok: Jász-Nagykun-Szolnok Megyei Levéltár, 1991, 351-367.

Bourdieu, Pierre. 'Az életrajzi illúzió.' (L'illusion biographique) In: Pierre Bourdieu (ed.), Gyakorlati észjárás. A társadalmi cselekvés elméletéról. Budapest: Napvilág Kiadó, 1994a, 68-76.

Bourdieu, Pierre. 'A családi szellem.' (The Family Spirit) In: Pierre Bourdieu (ed.), Gyakorlati észjárás. A társadalmi cselekvés elméletéröl. Budapest: Napvilág Kiadó, 1994b, 116-126.

Cartledge, Bryan. Will to Survive: A History of Hungary. London: Hurst, 2011.

Cucu-Oancea, Ozana. 'Using Diaries - A Real Challenge for the Social Scientist.' Procedia Social and Behavioral Sciences 92 (2013) 231-238.

Erdélyi, Gabriella. 'Differences between Western and East Central European Patterns of Remarriage and their Consequences for Children Living in Stepfamilies.' Hungarian Historical Review 8:4 (2019) 657-668.

Fodor, Ferenc. A Jászság életrajza. (The Biography of Jászság) Budapest: Szent István Társulat, 1942.

Frye, Northrop. 'Archetipikus kritika: a mítoszok elmélete.' (Archetypal Criticism: Theory of Myths) In: Northrop Frye (ed.), A kritika anatómiája. Négy esszé. (The Anatomy of Critics. Four Essays) Budapest: Helikon Kiadó, 1998, 63-112.

Greenwood, John D. A Conceptual History of Psychology. Boston: Hill Higher Education, 2007.

Gyáni, Gábor. 'Identitás, emlékezés, lokalitás.' (Identity, Remembering, Locality) In: Gábor Gyáni (ed.), Az elveszíthetö múlt. A tapasztalat mint emlékezet és történelem. Budapest: Nyitott Könyvmühely, 2010.

Győrffy, István. 'A Jászkunság nemessége 1699.' (Nobility of Jászkunság, 1699) Genealogiai Füzetek (1907).

Heckenast, Gusztáv. Ki kicsoda a Rákóczi szabadságharcban? (Who is who in the Rákóczi Independence War?) Budapest: História-MTA TTI, 2005.

Heinrichs, R. W. 'Historical Origins of Schizophrenia: Two Early Madmen and Their Illness.' Journal of the History of the Behavioral Sciences 39 (2003) 349-363.

Jajdelska, Elspeth. Silent Reading and the Birth of the Narrator. Toronto: University of Toronto Press, 2007. 
Jefferson, Thomas. In: Joyce Appleby and Terence Ball (eds.), Political Writings. Cambridge: Cambridge University Press, 1999.

Katona, Csaba and Eleonóra Kovács. 'A személyes emlékezet dokumentumai.' (Documents of Personal Remembering) Turul 87:2 (2014) 41-47.

Kiss, József. A pesti Invalidus Ház jászkunsági földesurasága, 1731-1745. (The landlordship of the Invaliderhus in Jászkunság, 1731-1745) Budapest: Akadémiai Kiadó, 1992.

Kiss, József. 'Húshagyókedd Árokszálláson 1740-ben.' (Shrove Tuesday in Jászárokszállás in 1740) In: László Pethő (ed.), Jászsági Évkönyv. (Jászság Yearbook) Jászberény: Jászsági Évkönyv Alapítvány, 1994, 69-81.

Kiss, József. 'Kulturális fejlődés és egyházi iskoláztatás Árokszálláson, 1730-1770-ig.' (Cultural development and parochial schools in Árokszállás between 1730 and 1770) In: László Pethő (ed.), Jászsági Évkönyv (Jászság Yearbook). Jászberény: Jászsági Évkönyv Alapítvány, 1996.

Kocsis, Gyula. A Jászság társadalma, népessége, gazdálkodása a XVI-XVII. században. (The Society, Population and Economy of Jászság in the $16^{\text {th }}$ and $17^{\text {th }}$ Centuries) Budapest: Akadémiai Kiadó, 2005.

Kónya, Anikó. 'Személyes múlt és történelem.' (Personal Past and History) In: Csaba Pléh, János László and Oláh A. Attila (eds.), Tanulás, kezdeményezés, alkotás: Barkóczi Ilona 75. születésnapjára (Learning, Initiating, Creating: for Ilona Barkóczi on her $75^{\text {th }}$ Birthday) Budapest: ELTE Eötvös Kiadó, 2001, 286-293.

Kövér, György. 'Énazonosság az ego-dokumentumokban. Napló, önéletírás, levelezés.' (Identity in Ego - Documents. Diary, Self-Biography, Correspondence) In: György Kövér (ed.), Biográfia és társadalomtörténet. (Biography and Social History) Budapest: Osiris Kiadó, 2014a, 99-123.

Kövér, György. 'A biográfia nehézségei.' (The Difficulties of Biography) In: György Kövér (ed.), Biográfia és társadalomtörténet (Biography and Social History). Budapest: Osiris Kiadó, 2014b, 17-39.

László, János. 'Történelem, elbeszélés, identitás.' (History, Narration and Identity) In: Orsolya Rákai and Zoltán Z. Kovács (eds.), A narratív identitás kérdései a társadalomtudományokban (Questions of Narrative Identity in Social Sciences). Budapest-Szeged: Gondolat Kiadói Kör - Pompeji, 2003, 156-172.

Lejeune, Philippe. 'How Do Diaries End?' In: Jeremy D. Popkin and Julie Rak (eds.), On Diary. University of Hawaii Press, 2009, 187-200.

Mikkonen, Jukka. 'The (Literary) Stories of Our Lives.' In: Garry Hagberg (ed.), Narrative and Self-Understanding. Palgrave Macmillan, 2019, 11-28.

Nagy, Iván. Magyarország családai czímerekkel és nemzedékrendi táblákkal (Families in Hungary with Coat of Arms and Generational Tables) Pest: Ráth Mór, 1861.

Papp, Izabella. Görög kereskedők a Jászkunságban. (Greek Traders in Jászkunság) Szolnok: JászNagykun-Szolnok Megyei Levéltár, 2004.

Ransel, David L. 'The Diary of a Merchant: Insights into Eighteenth-Century Plebeian Life.' The Russian Review 63:4 (2014) 594-608.

Sárdi Margit, S. Napló - könyv. Magyar nyelvü naplók 1800 elött. (Diary - Book. Hungarian Diaries Before 1800) Máriabesnyő: Attraktor, 2014.

Szabó, László. 'A jász öntudat alakváltozatai.' (Changing Patterns in the Jász Self-Image) In: László Selmeczi (ed.), Szolnok Megyei Múzeumi Évkönyv. (Yearbook of Szolnok County Museum) Szolnok: Damjanich János Múzeum, 1981, 129-148.

Tünde, Horvát M., Andrea Dúll, and János László. 'A helyveszteség vizsgálata migrációban lévő magyar fiatalok körében - kutatási beszámoló.' (Investigations on Loss of Place among Hungarian Youths in Migration - Research Report) Magyar Pszichológiai Szemle 61:1 (2006) 133-153.

Twain, Mark. Autobiography of Mark Twain. Volume 2. University of California Press, 2013. 


\section{ABOUT THE AUTHOR}

Gábor Csikós (1985) holds degrees in Psychology (MA) and History (MA). In 2019 he defended his Ph.D. thesis and started work at the Institute of History of the Hungarian Academy of Sciences. He also became a lecturer at the Psychology Institute of Károli Gáspár University of the Reformed Church in Hungary. His research interest focuses on social history, particularly rural history. He has so far edited six volumes; one of these was Nagy György's diary (Nemes Nagy György jászsági naplója), the source for the current study.

\section{NOTES}

1 This study was supported by the MTA BTK Lendület Ten Generations Research Group. I thank Paul Thatcher for proofreading the manuscript.

2 Twain 2013: 266.

3 Nagy 2017: 44.

4 Cucu-Oancea 2013.

5 Kövér 2014a; S. Sárdi 2014: 71-78.

6 Berne 1997: 66-68 'It is common knowledge, even proverbial, how much grandparents, alive or dead, influence the lives of their grandchildren. ... In general, grandparents, as mythology and clinical experience show, are regarded with awe or terror, just as parents can be regarded with admiration or fear.'

7 Nagy 2017: 51. He did not want to 'cause detrimentum (damage) due his advena (foreigner) state'.

8 Kiss 1994.

9 Greenwood, 2007: 1-30.

10 Heinrichs, R. W. 2003.

11 The word protocollum (charter) emphasizes the legal aspect of his book. Although he copied a lot of legal documents (including the rights proved by the Act of Redemption in 1745), most of the volume contains his personal impressions.

12 Gyáni 2010.

13 Nagy 2017: 62-64.

14 Mikkonen 2019.

15 Nagy 2017: 31.

16 Nagy 2017: 42: 'The succession of Her Majesty was seen with envious eyes and hearts by exterior courts and drags us to a bitter war.'

17 Nagy 2017: 62.

18 Nagy 2017: 49.

19 Nagy 2017: 68.

20 Bourdieu 1994a; Kónya 2001; Katona - Kovács 2014.

21 Lejeune 2009.

22 Jajdelska 2007: 4-6.

23 Cartledge 2011: 115-123.

24 Frye 1998.

25 Nagy 2017: 34.

26 Nagy 2017: 34-35.

27 Nagy 1861. 
28 For the dynamics of premodern stepfamilies, see Erdélyi 2019.

29 http://www.oldmapsonline.org/map/mzk/2619316409.

30 Horvát - Dúll - László 2006.

31 Nagy 2017: 30-33.

32 https://www.familysearch.org/ark:/61903/3:1:939J-15YW-6? $\mathrm{i}=152 \&$ cat $=45742$.

33 Kiss 1994.

34 Szabó 1981.

35 Győrffy 1907 and Fodor 1942: 213.

36 Kocsis 2005: 71.

37 Kiss 1994.

38 Nagy 2017: 83.

39 Nagy 2017: 51; 59.

40 Ransel 2014.

41 Papp 2004: 25-26.

42 Jefferson 1999: 549. The conflict of these views is demonstrated in the novel of Knut Hamsun, Growth of the Soil: "Can you earn more money in a day by working on the land than you could by working for us?" "Why, as to that, I can't say,"' answered Isak. 'It's just this way, you see- 'tis the land I'm here for. I've many souls and more beasts to keep alive—and 'tis the land that keeps us. "Tis our living."'

43 Nagy 2017: 67-72; 83.

44 Kiss 1996: 157.

45 Kiss 1992: 172-173.

46 Nagy 2017: 56; 61.

47 Nagy 2017: 50.

48 Nagy 2017: 36; 51.

49 Nagy 2017: 71.

50 Heckenast 297-298.

51 Nagy 2017: 29.

52 Nagy 2017: 38; 54.

53 Nagy 2017: 60, 63-64.

54 Nagy 2017: 79.

55 Kövér 2014b.

56 Bourdieu 1994b.

57 Berne 1997: 83-85; Boreczky 2004: 27-39; 135.

58 László 2003.

59 Nagy 2017: 57.

60 Nagy 2017: 59.

61 Nagy 2017: 39 (György Nagy also recorded that a widely circulated rumor stated that this rebellion was initiated by the son of Ferenc Rákóczi).

62 Nagy 2017: 61.

63 Bagi 1995: 58.

64 Botka 1991. 